\title{
Short-term application of prestimulation and increased automatic cluster remover threshold affect milking characteristics of grazing dairy cows in late lactation
}

\author{
J. P. Edwards, ${ }^{*}{ }^{1}{ }^{1}$ J. G. Jago, ${ }^{*}$ and N. Lopez-Villalobos $\dagger$ \\ *DairyNZ, Private Bag 3221, Hamilton 3240, New Zealand \\ †Institute of Veterinary, Animal and Biomedical Sciences, Massey University, Private Bag 11222, \\ Palmerston North 4442, New Zealand
}

\section{ABSTRACT}

It was hypothesized that reducing cow cluster-on time by increasing automatic cluster remover (ACR) thresholds above $0.4 \mathrm{~kg} / \mathrm{min}$ would require premilking stimulation of the mammary gland to maintain milk yield. This was tested by examining the interaction between 4 ACR thresholds and 3 premilking treatments over an 8-wk period with 96 mixed-age Friesian-Jersey cross cows being milked twice per day in late lactation (average production: $13.9 \mathrm{~kg} / \mathrm{d}$ ). The 3 premilking treatments were attach cluster immediately (control), attach cluster $60 \mathrm{~s}$ after entering the dairy (delay), or remove 2 squirts of foremilk from each quarter and attach cluster $60 \mathrm{~s}$ after entering the dairy (Prep). Four ACR thresholds were chosen, where the cluster was removed after the milk flow rate was less than 0.2 (ACR2), 0.4 (ACR4), 0.6 (ACR6), and $0.8 \mathrm{~kg} / \mathrm{min}$ (ACR8). Measurements included individual cow milk yield, cluster-on time, average milk flow rate, maximum milk flow rate, time from cluster attachment to average milk flow rate, milk yield in the first 2 min, time from maximum milk flow rate to end of milking, and the milk flow rate at predetermined intervals during each milking session. Composite milk samples were collected weekly at a.m. and p.m. milkings to determine composition and somatic cell count (SCC). On 3 occasions during the experiment, postmilking strip yield was measured. No interactions were detected between premilking treatment and ACR threshold in any of the measured variables. Cows receiving the Prep treatment had a 5 to $9 \%$ shorter cluster-on time than the control treatment. Milk yield, SCC, postmilking strip yield, and maximum flow rate were not different between the 3 premilking treatments. Cluster-on time of the ACR8 cows was 21 to $29 \%$ less than ACR2, but SCC and milk production variables were not different between the 4

Received September 24, 2012.

Accepted November 16, 2012.

${ }^{1}$ Corresponding author: Paul.Edwards@dairynz.co.nz end-of-milking treatments despite higher strip yields as ACR threshold increased. Increasing ACR threshold offers the potential to reduce the duration of milking without detriment to overall productivity. The results of the premilking treatments indicate that to achieve the most efficient routine, the operator should attach clusters as close as possible to the first bail in rotary dairies to increase bail utilization in pasture-based systems. If cluster attachment can be sped up and ACR threshold lifted, significant potential exists to decrease herd milking duration and improve labor productivity. Key words: milking duration, stimulation, automatic cluster remover

\section{INTRODUCTION}

The process of milking cows requires significant labor, accounting for up to $57 \%$ of a farm's total annual labor input in pasture-based systems (Taylor et al., 2009). With increasing herd sizes, the time required to milk herds may increase, putting even greater pressure on human resource efficiency. The cluster-on time of individual cows is a significant factor in determining herd milking duration and, thus, labor requirement at a herd level.

International studies have reported that the choice of automatic cluster remover (ACR) milk flow rate threshold influences the cluster-on time of cows, with no effect on production or udder health (Rasmussen, 1993; Stewart et al., 2002). The ACR thresholds tested ranged from 0.2 to $0.8 \mathrm{~kg} / \mathrm{min}$. However, in these studies, cows were milked following premilking routines that involved prestimulation, which is a legal requirement in the European Union and United States (EU, 2004; FDA, 2009). The routine of Rasmussen (1993) included washing teats and the drawing of 5 squirts of foremilk from each quarter. This is not common practice in pasture-based systems where minimal premilking routines are used; for example, in rotary dairies, clusters are attached, without prestimulation, immediately upon entry to the platform or delayed until several bails after the entrance. 
The international results led to similar research in New Zealand (Jago et al., 2010a) using a genetic strain of cow for which milking routines with prestimulation have not been common practice since the 1970s (Phillips, 1987). Two different ACR thresholds were evaluated: 0.2 and $0.4 \mathrm{~kg} / \mathrm{min}$ (Jago et al., 2010a; Burke and Jago, 2011). The authors concluded that with the higher ACR threshold, the cluster-on time of cows decreased with minimal effects on milk production, clinical mastitis, and SCC (Burke and Jago, 2011). Further decreases in cluster-on time may be possible by increasing ACR thresholds from $0.4 \mathrm{~kg} / \mathrm{min}$ to the $0.8 \mathrm{~kg} / \mathrm{min}$ level tested internationally. Possible consequences of increasing ACR thresholds to $0.8 \mathrm{~kg} / \mathrm{min}$ may be greater SCC and lower milk yield. Studies have indicated that without adequate prestimulation, there might be a significant amount of milk to be harvested after the flow rate falls below $0.8 \mathrm{~kg} / \mathrm{min}$ near the end of milking (Bruckmaier and Blum, 1996). Premilking stimulation has not been common in pasture-based systems after research by Phillips (1987) demonstrated that it was not required to maintain milk production, which has allowed for a greater number of cows per labor unit compared with housed systems. Premilking stimulation has been reported to reduce the incidence of bimodal milk flow profiles compared with no premilking stimulation (Bruckmaier and Blum, 1996). Bimodal milk flow profiles occur due to the delayed availability of alveolar milk following the removal of the cisternal milk fraction, which can result in collapsed mammary ducts and potentially reduced milk flow rates (Bruckmaier and Blum, 1996), affecting the use of high ACR thresholds. Thus, the adoption of a routine that includes premilking stimulation may be necessary to ensure that milk production is not adversely affected by higher ACR thresholds.

Over lactation, the degree of udder fill is reduced as milk yield decreases. At lower degrees of udder fill, moving milk from the alveoli to the cistern requires greater contraction by myoepithelial cells (Bruckmaier and Hilger, 2001), thus delaying milk ejection. Therefore, the response to stimulation is greater in late lactation than early lactation (Bruckmaier et al., 1995; Bruckmaier and Hilger, 2001). For this reason, cows in late lactation were chosen for this study. Also, cows in late lactation are more likely to have sufficient cisteral capacity to compensate for early cluster detachment. The objective of this experiment was to evaluate potential strategies of reducing individual cow cluster-on time and the effects on milk yield, and indicators of udder health.

It was hypothesized that reducing cow cluster-on time by increasing ACR thresholds above $0.4 \mathrm{~kg} / \mathrm{min}$ required prestimulation of the mammary gland to maintain milk yield. This was tested by examining the interaction between 4 ACR thresholds and 3 premilking treatments in late-lactation cows.

\section{MATERIALS AND METHODS}

\section{Animals}

The study was conducted on 96 mixed-age FriesianJersey cross cows at the DairyNZ Lye Farm (Hamilton, New Zealand) from January to April 2011. The use of animals was approved by the Ruakura Animal Ethics Committee. Prior to and during the experiment, the cows were managed as one herd and rotationally grazed on predominantly perennial ryegrass pasture (Macdonald and Penno, 1998). The herd was milked in the morning between 0700 and $0830 \mathrm{~h}$ and in the afternoon between 1500 and $1630 \mathrm{~h}$, to maintain a consistent milking interval, through a 30 bail rotary dairy (GEA Farm Technologies GmbH, Bönen, Germany) with plant vacuum set at $42 \mathrm{kPa}$. Postmilking, a commercially available teat sanitizer (Teat-Guard Plus; Ecolab Inc., St. Paul, MN) was applied manually to each cow by pressurized spray.

\section{Experimental Design}

The experiment was designed in a $3 \times 4$ factorial arrangement. Three premilking treatments were selected to assess the impact of premilking stimulation; these treatments were crossed over. The first routine was a control, where the clusters were attached at the first bail after cows had walked onto the platform. In the second treatment, tactile stimulation (Prep) was applied by removing 2 squirts of foremilk from each quarter, followed by cluster attachment $60 \mathrm{~s}$ after entering the dairy. The time taken to remove foremilk was around $15 \mathrm{~s}$, resulting in a 45-s delay before cluster attachment. The third premilking treatment was delayed cluster attachment without prestimulation. The cows entered the platform and were exposed to the background noises associated with milking before cluster attachment 60 s later, the same point in the dairy as the Prep treatment. Delaying cluster attachment is common practice on Australasian farms, consistent with recommendations for timing of cluster attachment (Brightling et al., 1998). This treatment also allowed for the separation of the effects of delayed cluster attachment and prestimulation. An operator was standing at the first bail attaching clusters on control cows and stimulating Prep cows, and a second operator was attaching clusters on Prep and delay cows at a position determined by the rotary platform speed. 
For each premilking strategy, 4 ACR thresholds were imposed by the herd management system: 0.2 (ACR2), 0.4 (ACR4), 0.6 (ACR6), and $0.8 \mathrm{~kg} / \mathrm{min}$ (ACR8). If the cow's milk flow rate remained below the respective threshold level for greater than $4 \mathrm{~s}$, the ACR was activated and the cluster was removed within $5 \mathrm{~s}$. All treatments were balanced for DIM, cluster-on time, yield, SCC, breed, and age.

The first week of the experiment was used to gather baseline data to be used as a covariate. All cows were milked as per the control treatment, with clusters attached at entry and the ACR threshold set at $0.35 \mathrm{~kg} /$ min, which was standard on this research farm. The second week of the experiment was used to transition the cows to the new ACR threshold. On the first day of the second week, ACR2 and ACR4 cows were changed from $0.35 \mathrm{~kg} / \mathrm{min}$ to their respective thresholds. At the same time, cows on the ACR6 and ACR8 treatments were increased to $0.5 \mathrm{~kg} / \mathrm{min}$ and remained there for 3 $\mathrm{d}$ before changing to their final ACR thresholds of 0.6 and $0.8 \mathrm{~kg} / \mathrm{min}$, respectively. Cows remained on the allocated ACR treatment for the remainder of the experiment. In wk 3, the premilking treatments commenced, and were applied for $2 \mathrm{wk}$ (phase 1). At wk 5 , the cows on each of the premilking treatments were switched to another treatment (half of the cows in each) and this was applied for $2 \mathrm{wk}$ (phase 2). At wk 7, the premilking treatments were switched to the one remaining treatment, which was applied for a final 2 wk (phase 3 ).

\section{Measurements}

The dairy was fitted with Metatron P21 milk meters (GEA Farm Technologies GmbH) at each bail. The herd management software was set to record individual cow milk yield, cluster-on time (cluster on to cluster off), average milk flow rate (from initiation of milk flow to cluster removal), maximum milk flow rate, time from cluster attachment to average milk flow rate, milk yield in the first $2 \mathrm{~min}$, time from maximum milk flow rate to end of milking, and the average milk flow rate in 15 -s intervals up to 4 min, over 30 -s intervals between 4 to $7 \mathrm{~min}$, and over 60 -s intervals from 7 to $10 \mathrm{~min}$ at each milking session. Milk meter samples were collected weekly to determine the composition using a MilkoScan 133B analyzer (Foss Electric A/S, Hillerød, Denmark) and SCC using an automated cell counter (Fossomatic 5000; Foss Electric A/S). At the end of each phase, postmilking strip yield was measured by reattaching the cluster within 2 min of the end of milking. Downward pressure was applied until no further milk could be removed from the udder. The operator applying the Prep routine was recorded at each session.

\section{Statistical Analysis}

The milking data from d 6 to 12 of each phase were analyzed using a linear mixed model that included the fixed effects of operator, phase, session, ACR, and premilking treatment, and their interaction and milking characteristics prior to the application of treatments as a covariate and cow and phase within cow as random effects. Somatic cell count data were normalized using a logarithm (base 10) transformation, and strip yield data normalized using a square root transformation. Average milk flow profiles were derived from least square means of the average milk flow rate during each of the recorded time intervals. A milk flow profile was defined as bimodal if during the first $75 \mathrm{~s}$ the milk flow rate fell by more than $0.1 \mathrm{~kg} / \mathrm{min}$ from one time interval to the next, the milk flow rate during the second and third time intervals after either remained the same or increased, and the milk flow rate thereafter was greater than zero. All analyses were undertaken using GenStat 13.2 (VSN International Ltd., Hemel Hampstead, UK).

\section{RESULTS}

\section{Premilking Treatment}

No interactions were detected between premilking treatment and ACR threshold. The main effects are, therefore, presented separately. Cows receiving the Prep treatment had a shorter cluster-on time (5-9\%; $P<0.001)$ than the control and delay treatments, which did not differ from each other (Figure 1; Table 1). The delay treatment was not significantly different from the control and, on average, both had bimodally shaped flow curves, although milk flow profiles were variable between animals. The Prep treatment reduced the number of cows with bimodally shaped milk flow curves $(P<0.001)$. Milk production was not affected by treatment, but there was a small difference in average milk flow rate $(P<0.001)$ and maximum milk flow rate (a.m. only; $P<0.05$ ), this being greater for Prep cows. Time from cluster attachment to average milk flow rate was shorter $(P<0.001)$ and the time from maximum flow rate to end of milking was longer $(P<$ 0.05) for the Prep routine. Cows on the Prep treatment had a greater volume of milk harvested in the first 2 $\min (P<0.001)$ and greater cumulative yield in the first $195 \mathrm{~s}(P<0.001)$; however, no difference existed thereafter. Strip yield and SCC were not different between treatments.

\section{ACR Thresholds}

Increasing ACR threshold affected cluster-on time (Table 2). In comparison to the ACR2 treatment, the 
a)

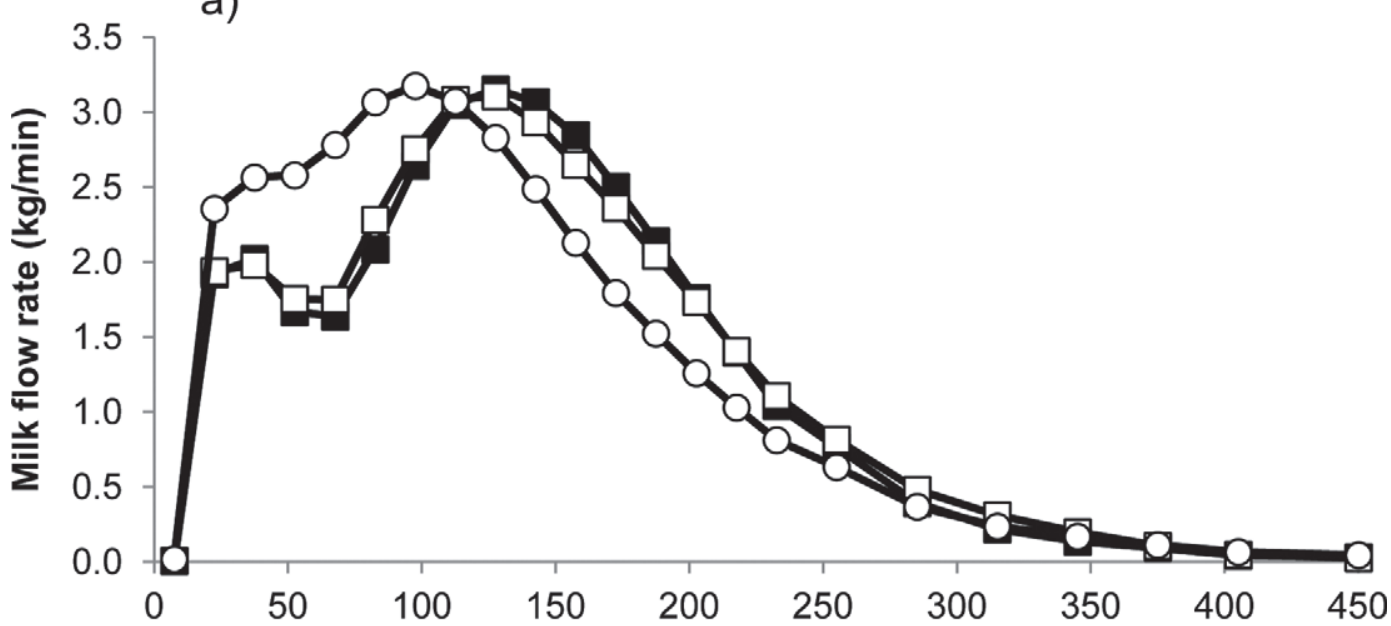

b)

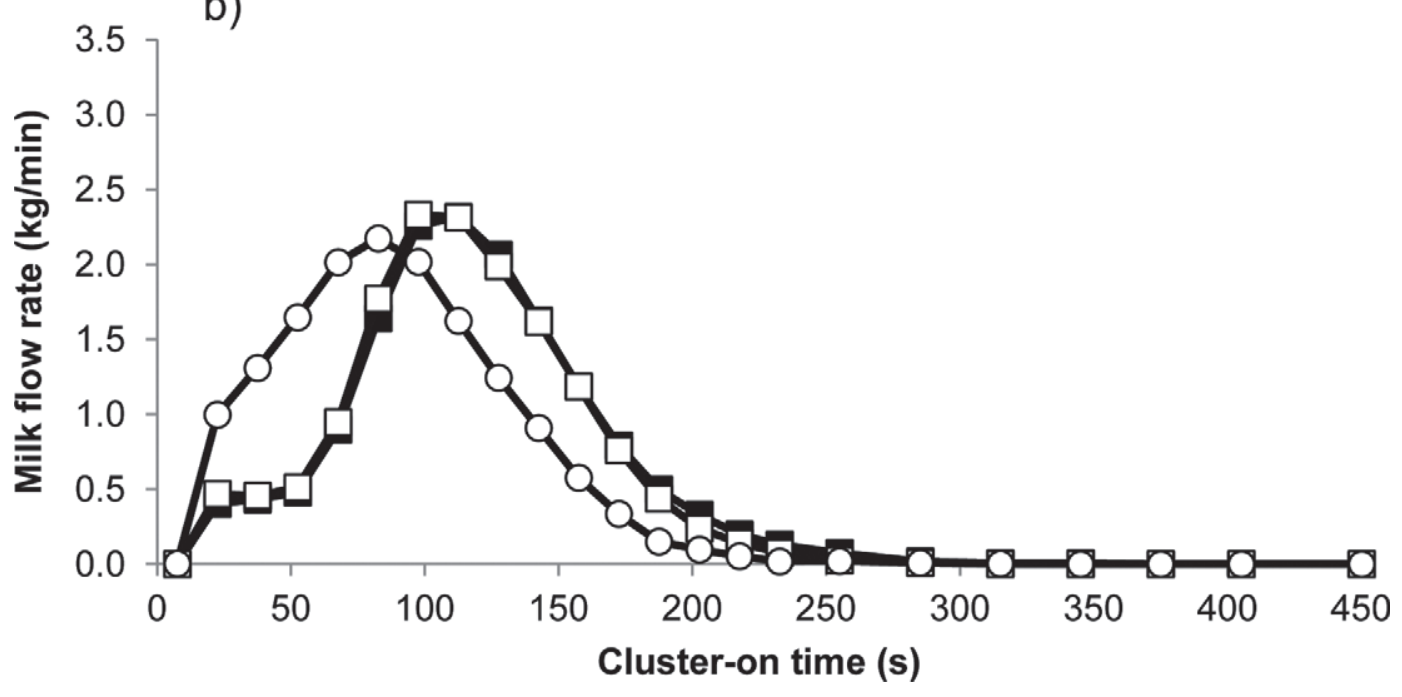

Figure 1. Average milk flow curves for 3 premilking routines: control ( $\square$ ), delay ( $\square$ ), and Prep (○) at a.m. (a) and p.m. (b) milking sessions. Control: attach cluster immediately; delay: attach cluster $60 \mathrm{~s}$ after entering the dairy; Prep: 2-squirt strip from each quarter and attach cluster $60 \mathrm{~s}$ after entering the dairy.

milking time per cow on the ACR8 treatment was 72 and 81 s less at a.m. and p.m. milkings $(21-29 \% ; P<$ $0.001)$. Time to average milk flow rate decreased and the number of bimodal milk flow profiles increased with increasing ACR threshold at the p.m. milking only $(P$ $<0.05)$. The average milk flow rate was greater $(P<$ $0.001)$ and decline duration significantly lower $(P<$ 0.001 ) in the higher-ACR thresholds. An increase in strip yield was recorded with increasing ACR threshold $(P<0.05)$. Somatic cell count and milk production variables were not affected by treatment.

\section{DISCUSSION}

Milk production variables were not affected by ACR threshold or premilking treatment during this short- term experiment. None of the premilking treatments influenced the effect of changing ACR thresholds for any of the variables measured. Increasing ACR threshold above $0.4 \mathrm{~kg} / \mathrm{min}$ reduced cow cluster-on time without compromising milk yield. As a result, the hypothesis that increasing ACR thresholds above $0.4 \mathrm{~kg} / \mathrm{min}$ requires prestimulation of the mammary gland to maintain milk yield was rejected. No interaction between premilking treatment and ACR threshold was detected and, thus, the results of each are discussed separately.

The Prep treatment decreased cow cluster-on time, while the delay treatment did not. A decrease in cow cluster-on time in response to the Prep treatment was also reported by Bruckmaier and Blum (1996). A major effect of treatment was the shape of the milk flow curve during the first half of milking (Figure 1). A bimodal 
Table 1. Effect of 3 premilking treatments (control, delay, and Prep) on milking characteristics, SCC, and strip yield

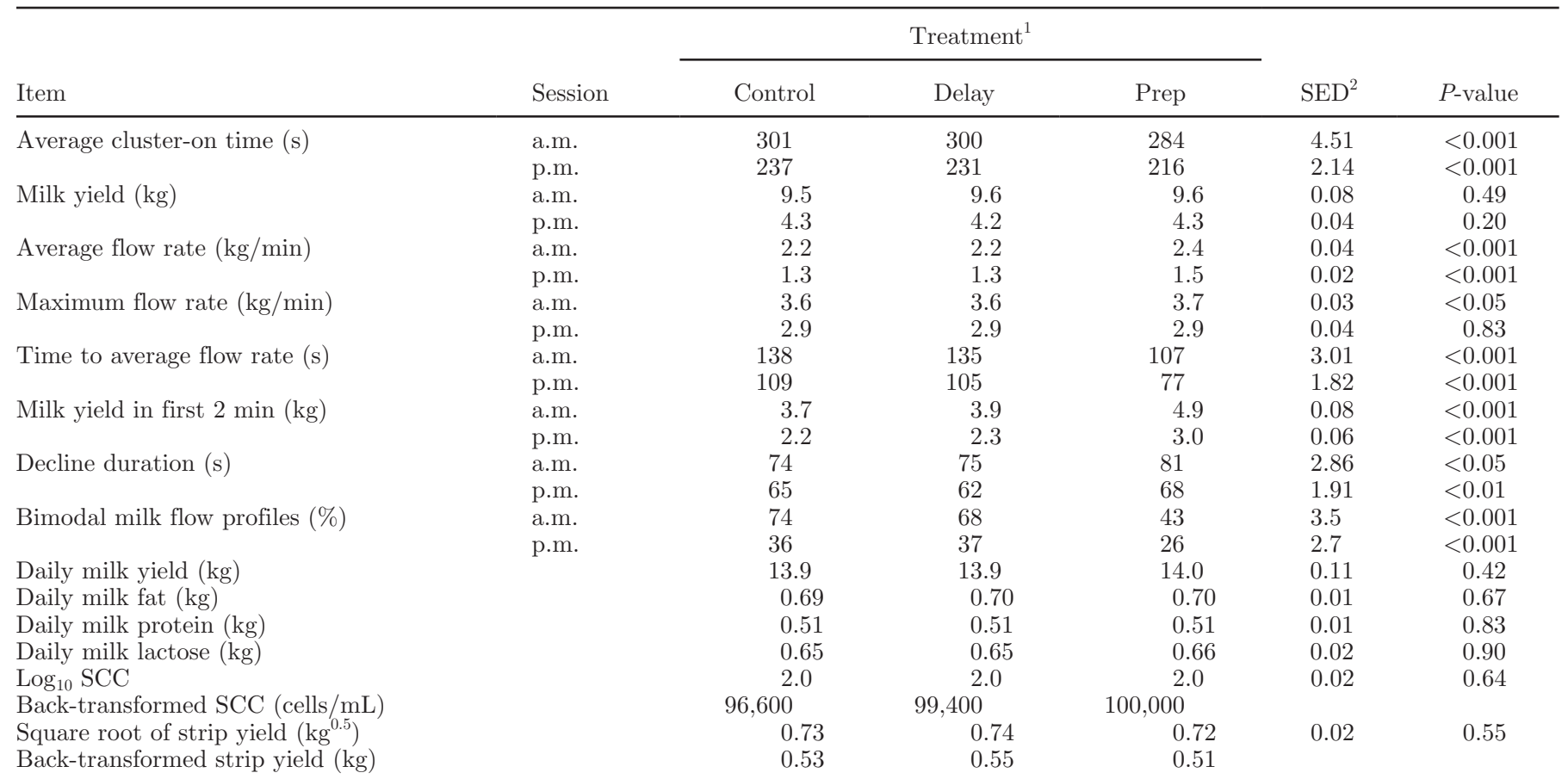

${ }^{1}$ Control: attach cluster immediately; delay: attach cluster after 60 seconds; Prep: 2-squirt strip from each quarter and attach cluster after $60 \mathrm{~s}$.

${ }^{2}$ Standard error of the difference.

Table 2. Effect of 4 automatic cluster remover (ACR) thresholds (ACR2, ACR4, ACR6, and ACR8) on milking characteristics, SCC, and strip yield

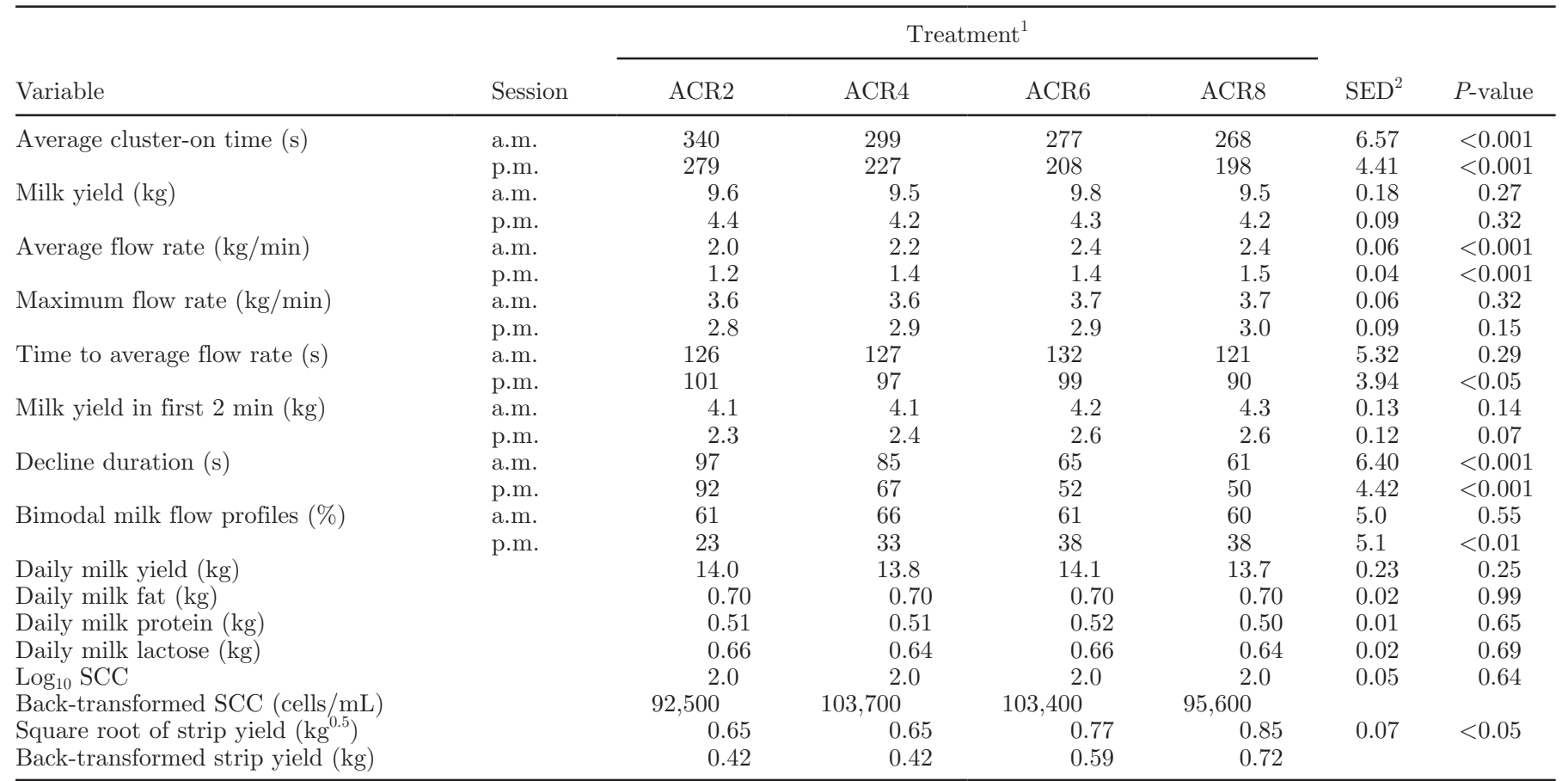

${ }^{1}$ Cluster was removed after the milk flow rate was less than $0.2 \mathrm{~kg} / \mathrm{min}$ (ACR2), $0.4 \mathrm{~kg} / \mathrm{min}$ (ACR4), $0.6 \mathrm{~kg} / \mathrm{min}(\mathrm{ACR} 6)$, and $0.8 \mathrm{~kg} / \mathrm{min}$ (ACR8).

${ }^{2}$ Standard error of the difference. 
milk flow curve was anticipated for the control treatment due to low milk yield in late lactation and lack of premilking stimulation. The average milk flow curve of Prep cows was not bimodal like that of control or delay cows, resulting in a shorter time to average milk flow rate and more milk being harvested in the first $195 \mathrm{~s}$. However, for the latter half of milking, from maximum flow rate to the end of milking, the Prep treatment was longer than the control, negating some of the earlier benefit. The control and delay cows had a similar time to average milk flow rate, which was longer than that of the Prep treatment, indicating that for most cows, milk ejection is not initiated until the udder is touched by the machine or other means. The shape of the flow curve was similar for the delay and control treatments, explaining the lack of difference in cluster-on time and milk yield between the two. All 3 premilking treatments achieved a similar maximum milk flow rate, although the Prep treatment was slightly greater at morning milkings. In contrast, Bruckmaier and Blum (1996) reported larger maximum flow rate increases in response to prestimulation by removal of 1 to 2 squirts of foremilk and a short manual massage. Maximum flow rate was reached earlier in the Prep treatment but due to the differences in flow curves near the end of milking, the decline duration was longer, resulting in a net 17 $\mathrm{s}$ (a.m.) or $20 \mathrm{~s}$ (p.m.) reduction in cluster attachment time. However, the time cost of applying stimulation and delaying cluster attachment (60 s) was more than the reduction in cow cluster-on time, meaning that the net result was an increase in the time the cow spent in the dairy. This result is supported by Bruckmaier et al. (1995). Additionally, there was no benefit in milk yield, nor a change in strip yield or SCC as a result of stimulation. Thus, despite showing a response to prestimulation, neither form of premilking treatment gave an advantage in reducing overall milking time using cows bred in pasture-based production systems, in which premilking routines with prestimulation have not been routinely practiced for approximately $40 \mathrm{yr}$.

The lack of interaction can probably be explained by the flow curves (Figure 1). The slope of the flow curves appears different between treatments before, but not after maximum milk flow, despite maximum flow being reached earlier in the Prep treatment. This is similar to the results of Sandrucci et al. (2007), who reported a shorter incline phase but no change in the decline phase following stimulation. The results of the lower ACR thresholds (ACR2 and ACR4) are consistent with studies of Jago et al. (2010a) and Rasmussen (1993), which were studies conducted over a longer time period. Use of higher ACR thresholds resulted in greater average milk flow rates, so despite the shorter cluster-on time, no decrease in yield occurred. Conversely, strip yield was higher, indicating that more milk remained as a result of the cluster being removed earlier. The strip yields in the lowest ACR threshold were $0.35 \mathrm{~kg}$ less than the highest ACR threshold. Such a small difference (of $2.5 \%$ ) may explain why cows were able to, over the relatively short duration of the trial, maintain daily milk yield with shorter durations of milking. Additionally, this small increase in strip yield did not result in a higher SCC, a finding supported by Burke and Jago (2011) and Clarke et al. (2008). However, as this was a short-term study in late lactation, the effect of ACR thresholds higher than $0.4 \mathrm{~kg} / \mathrm{min}$ on milk production and SCC requires validation over a whole lactation. The results indicate that in late lactation, operators are not restricted to a threshold of $0.4 \mathrm{~kg} / \mathrm{min}$ when using a minimal premilking routine without stimulation and this offers potential to reduce the duration of milking further without detriment to overall productivity.

Premilking routine and ACR treatments produced different effects at the a.m. and p.m. milkings for some milking characteristics. Variation between a.m. and p.m. results was likely due to differences in milk yield as a consequence of a 16-h milking interval overnight and an 8-h interval during the day. This possibly resulted in a smaller cisternal milk yield at the p.m. milking and subsequently fewer bimodally shaped milk flow profiles, as initial flow rates remained low (Figure 1b). Similarly shaped milk flow profiles were reported by Bruckmaier and Hilger (2001) for 8- and 12-h milking intervals at late lactation. Following this theory, that at the p.m. milking less cisternal milk resulted in fewer bimodal milk flow profiles, the increasing bimodality recorded at p.m. milkings at higher ACR thresholds is possibly due to a greater cisternal volume as a consequence of greater residual milk, observed as higher strip yields. This is supported by a shorter time to average milk flow rate at the p.m. milking with higher ACR thresholds. It is likely this result is unique to situations with low milk yield, such as the p.m. milking during late lactation, as more cisternal milk could be expected to decrease bimodality (e.g., during peak lactation; Bruckmaier and Hilger, 2001). The variation between a.m. and p.m. may necessitate different rules at each milking, such as a longer minimum milking time at the p.m. milking for cows not prestimulated due to their low initial milk flow rates.

The results achieved from prestimulation and increased ACR thresholds can be used to devise effective strategies to reduce herd milking duration. In particular, the results from the delay treatment contradict guidelines to stand several bails from the entranceway in rotary dairies (Brightling et al., 1998), which decreases bail use. Increasing bail use by standing as close as possible to the first bail means clusters can be used 
for milk harvesting for a greater amount of time in each rotation. In addition, the operator will arguably have better control of cow flow. At the end of milking, an increase in ACR threshold resulted in shorter cow cluster-on time. This result is most applicable to rotary dairies, the majority of which tend to milk larger herds and have ACR installed (Cuthbert, 2008; Mackinnon et al., 2010). In rotary dairies, a reduction in cow cluster-on time will result in a decrease in the number of cows requiring a second rotation at a given platform speed, or allow the same number of go-around cows at a faster platform speed. Alternatively, for farmers building new dairies, a smaller size with fewer bails may be constructed to achieve the same level of throughput for less capital cost. Increasing platform speed may be limited under some circumstances due to the operator not being able to attach clusters at a fast enough rate (e.g. $>60$ bail rotaries with 1 operator attaching clusters). Increasing the ACR threshold is less applicable to the herringbone dairy because in some countries it is less common to have ACR installed (Cuthbert, 2008; Mackinnon et al., 2010) and row times are still limited to the slowest milking cow, meaning a reduction in herd milking duration is not assured (Stewart et al., 2002). Accordingly, Clarke et al. (2004) concluded that the installation of ACR in herringbone dairies would be an expensive capital investment if only used to shorten cow cluster-on time. However, the authors found merit in the application of a maximum milking time, which has subsequently been supported by the results of Jago et al. (2010b). Overall, implementing both strategies of attaching clusters as close as possible to the cow entry and using a higher ACR threshold in rotary dairies will achieve the greatest benefit, as long as the operator work routine is not a constraint.

Large variations in milking speed and flow curves were recorded between individual animals in the present experiment, and as milk flow rate is reported to be heritable (Zwald et al., 2005), potential exists to harness the efficiency benefit of those cows that did not display bimodal flow curves or a delay in milk ejection when milked without a premilking stimulation. In the past, the selection of animals on milking characteristics has successfully removed the requirement for a premilking stimulus to maximize milk production in New Zealand (Phillips, 1987). Applying premilking stimulation to a cross section of the national herd in 1958 resulted in a milk fat response of $33 \%$, which had reduced to zero 20 yr later (Phillips, 1987). This result was achieved through a combination of using males that sired progeny with low stimulus requirements, and selection pressure on farm, whereby premilking stimulation was discontinued and cows that failed to adjust to the change in system were culled due to poor production. Similarly, a minority of cows may be unsuitable if adopting a higher ACR threshold and, thus, require culling. In the future, if selecting for cows with efficient milk flow curves, any associations with detrimental factors, such as clinical mastitis, need to be assessed before selectively breeding for such animals.

\section{CONCLUSIONS}

Increasing ACR threshold reduced individual cow cluster-on time and, thus, can potentially be used to decrease herd milking duration without negatively affecting milk yield or SCC over the short term in late lactation. The premilking treatments examined did not reduce the amount of time cows spent on the rotary platform. Premilking stimulation, in the form of forestripping, was not required at higher ACR thresholds to maintain milk yield in New Zealand cows that have not been accustomed to prestimulation routines for the past 40 yr. Consequently, operators should attach clusters as close as possible to the first bail in rotary dairies to increase bail utilization.

\section{ACKNOWLEDGMENTS}

This study was part of a program of research funded by DairyNZ (Hamilton, New Zealand). The authors acknowledge DairyNZ Lye Farm (Hamilton, New Zealand) staff for animal management and milking, the Newstead (New Zealand) technical team, Barbara Dow (DairyNZ) for assistance with the data analysis, and David Lindsey (Perth, Western Australia) for assistance with manuscript structure.

\section{REFERENCES}

Brightling, P., G. A. Mein, J. Malmo, and D. P. Ryan. 1998. Countdown Downunder: Farm Guidelines for Mastitis Control. Dairy Research and Development Corporation, Melbourne, Australia.

Bruckmaier, R. M., and J. W. Blum. 1996. Simultaneous recording of oxytocin release, milk ejection and milk flow during milking of dairy cows with and without prestimulation. J. Dairy Res. 63:201-208. http://dx.doi.org/10.1017/S0022029900031708.

Bruckmaier, R. M., and M. Hilger. 2001. Milk ejection in dairy cows at different degrees of udder filling. J. Dairy Res. 68:369-376. http://dx.doi.org/10.1017/S0022029901005015.

Bruckmaier, R. M., E. Rothenanger, and J. W. Blum. 1995. Milking characteristics in dairy cows of different breeds from different farms and during the course of lactation. J. Anim. Breed. Genet. 112:293-302. http://dx.doi.org/10.1111/j.1439-0388.1995. tb00569.x.

Burke, J. K., and J. G. Jago. 2011. Comparing somatic cell counts, production and milking durations of dairy cows when milked at two automatic cup removal flow-rate thresholds. Anim. Prod. Sci. 51:920-924. http://dx.doi.org/10.1071/AN11042.

Clarke, T., E. M. Cuthbertson, R. K. Greenall, M. C. Hannah, E. Jongman, and D. Shoesmith. 2004. Milking regimes to shorten milking duration. J. Dairy Res. 71:419-426. http://dx.doi.org/10.1017/ S0022029904000421. 
Clarke, T., E. M. Cuthbertson, R. K. Greenall, M. C. Hannah, and D. Shoesmith. 2008. Incomplete milking has no detectable effect on somatic cell count but increased cell count appears to increase strip yield. Aust. J. Exp. Agric. 48:1161-1167. http://dx.doi. org/10.1071/EA07259.

Cuthbert, S. 2008. DairyNZ milking practices and technology use survey. Livestock Improvement Corporation (LIC), Hamilton, New Zealand.

EU (European Union). 2004. Annex III, Section IX, Chapter I, Part II, Subpart B, Point 1(b) of Regulation (EC) No. 853/2004 laying down specific hygiene rules for food of animal origin. Off. J. Eur. L 226:22-82. http://eur-lex.europa.eu/LexUriServ/LexUriServ.do ?uri=OJ:L:2004:226:0022:0082:EN:PDF.

FDA (Food and Drug Administration). 2009. Item 13r. MilkingFlanks, udders and teats. Pages 47-48 in Grade "A" Pasteurized Milk Ordinance. Department of Health and Human Services, Washington, DC. http://www.fda.gov/downloads/Food/ FoodSafety/Product-SpecificInformation/MilkSafety/National ConferenceonInterstateMilkShipmentsNCIMSModelDocuments/ UCM209789.pdf.

Jago, J. G., J. L. Burke, and J. H. Williamson. 2010a. Effect of automatic cluster remover settings on production, udder health, and milking duration. J. Dairy Sci. 93:2541-2549. http://dx.doi. org $/ 10.3168 /$ jds.2009-2949.

Jago, J. G., J. E. McGowan, and J. H. Williamson. 2010b. Effect of setting a maximum milking time, from peak lactation, on production, milking time and udder health. N. Z. Vet. J. 58:246-252. http://dx.doi.org/10.1080/00480169.2010.69298.

Macdonald, K. A., and J. W. Penno. 1998. Management decision rules to optimise milksolids production on dairy farms. Proc. N.Z. Soc. Anim. Prod. 58:132-135.
Mackinnon, D., M. Oliver, and D. Ashton. 2010. Australian dairy industry: Technology and management practices, 2008-09. ABAREBRS Research Report 10.11. Australian Bureau of Agricultural and Resource Economics and Sciences-Bureau of Rural Sciences (ABARE-BRS), Canberra, Australia. http://adl.brs.gov.au/data/ warehouse/pe_abarebrs99001757/RR10.11_dairy_REPORT.pdf.

Phillips, D. S. M. 1987. Long-term change in yield response to premilking preparation. N. Z. J. Agric. Res. 30:317-323. http:// dx.doi.org/10.1080/00288233.1987.10421890.

Rasmussen, M. D. 1993. Influence of switch-level of automatic cluster removers on milking performance and udder health. J. Dairy Res. 60:287-297. http://dx.doi.org/10.1017/S0022029900027631.

Sandrucci, A., A. Tamburini, L. Bava, and M. Zucali. 2007. Factors affecting milk flow traits in dairy cows: results of a field study. J. Dairy Sci. 90:1159-1167. http://dx.doi.org/10.3168/jds.S00220302(07)71602-8.

Stewart, S., S. Godden, P. Rapnicki, D. Reid, A. Johnson, and S. Eicker. 2002. Effects of automatic cluster remover settings on average milking duration, milk flow, and milk yield. J. Dairy Sci. 85:818823. http://dx.doi.org/10.3168/jds.S0022-0302(02)74141-6.

Taylor, G., L. van der Sande, and R. Douglas. 2009. Smarter not harder: Improving labour productivity in the primary sector. Accessed Aug. 29, 2012. http://maxa.maf.govt.nz/sff/aboutprojects/search/05-028/technical-report.pdf.

Zwald, N. R., K. A. Weigel, Y. M. Chang, R. D. Welper, and J. S. Clay. 2005. Genetic evaluation of dairy sires for milking duration using electronically recorded milking mimes of their daughters. J. Dairy Sci. 88:1192-1198. http://dx.doi.org/10.3168/jds.S0022$0302(05) 72785-5$ 